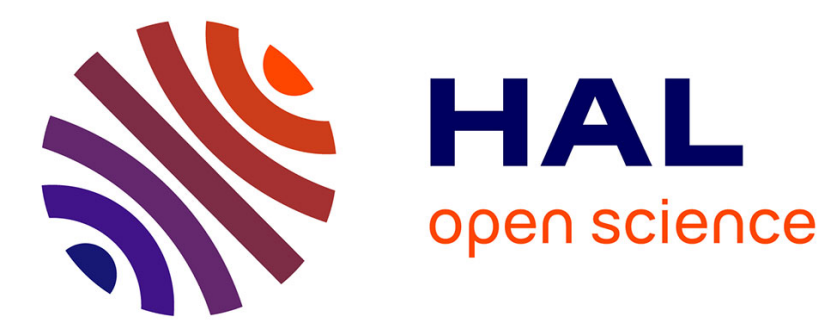

\title{
Locating North African microrefugia for mountain tree species from landscape ruggedness and fossil records
}

Yassine El Hasnaoui, Nadia Mhammdi, Lisa Bajolle, Majda Nourelbait, Ilham Bouimetarhan, Rachid Cheddadi

\section{- To cite this version:}

Yassine El Hasnaoui, Nadia Mhammdi, Lisa Bajolle, Majda Nourelbait, Ilham Bouimetarhan, et al.. Locating North African microrefugia for mountain tree species from landscape ruggedness and fossil records. Journal of African Earth Sciences, 2020, 172, pp.103996. 10.1016/j.jafrearsci.2020.103996 . hal-03099264

\section{HAL Id: hal-03099264 \\ https://hal.umontpellier.fr/hal-03099264}

Submitted on 7 Jan 2021

HAL is a multi-disciplinary open access archive for the deposit and dissemination of scientific research documents, whether they are published or not. The documents may come from teaching and research institutions in France or abroad, or from public or private research centers.
L'archive ouverte pluridisciplinaire HAL, est destinée au dépôt et à la diffusion de documents scientifiques de niveau recherche, publiés ou non, émanant des établissements d'enseignement et de recherche français ou étrangers, des laboratoires publics ou privés. 


\section{Locating North African microrefugia for mountain tree species from landscape ruggedness and fossil records}

Yassine El Hasnaoui ${ }^{1}$, Nadia Mhammdi ${ }^{1}$, Lisa Bajolle ${ }^{2}$, Majda Nourelbait ${ }^{3}$, Ilham Bouimetarhan $^{4,5}$ and Rachid Cheddadi ${ }^{2, *}$

1 University Mohammed V, Institut Scientifique, GEOPAC Research Center, Geophysic and Naturels Hazards Laboratory, Rabat, Morocco

${ }^{2}$ ISEM, University of Montpellier, CNRS, IRD, EPHE, Montpellier, France

${ }^{3}$ Laboratoire Géosciences Marines et Sciences du sol, University Chouaib Doukkali, El Jadida, Morocco

${ }^{4}$ Marum-Centre for Marine Environmental Sciences, University of Bremen, Germany ${ }^{5}$ Faculté des Sciences Appliquées-Université Ibn Zohr of Agadir, Morocco

${ }^{*}$ Corresponding author: elhasnaoui.yassin@gmail.com 


\section{ABSTRACT}

In order to optimize conservation policies for endangered plant species in North Africa and minimize the investment of the public resources we explore the capacity of a mountain plant species to persist locally in restricted natural areas. Palaeoecological studies have shown that plant species survived major global climate changes within refugia which offered suitable condition for their long term persistence. Our study aims at identifying potential mountains areas which may play the role of modern microrefugia for preserving locally endangered plant species.

We analysed the mountain ruggedness of an area in the North-East of the Middle Atlas mountains where a population of an endangered plant species, Cedrus atlantica, is isolated today around lake Tameda. In addition, we collected a sediment core in the lake to investigate the recent history of the species with the local environmental changes. We compared the terrain and fossil analyses with an area in the Rif mountains where the terrain rugosity is lighter than in the Middle Atlas and where Atlas cedar populations occur as well.

Our results show that the Atlas cedar is better preserved in terrains with high rugosity because they offer a wider panel of suitable microclimates for the species persistence and they restrict the number of inhabitants as well which, de facto, reduces the anthropogenic disturbances.

We have carried out this analysis at a very small scale (less than $40 \mathrm{~km}^{2}$ ). A more exhaustive analysis of the terrain rugosity over the Atlas and Rif mountains, combined with historical data, will help to identify more suitable refugial areas for preserving the species at a larger scale. Protecting these refugial areas over decades from any anthropogenic activity should be possible at a minimal cost and would represent an immediate response to the ongoing climate change for preserving endangered species.

Keywords: Microrefugia, Holocene, Morocco, Mountain species, Atlas cedar conservation 


\section{INTRODUCTION}

The ecological responses to recent climate change show that plant species are facing major challenges for persisting in their current range (Wiens, 2016). In Africa, the threat for most species combines now the ongoing climate change and the increasing direct anthropogenic impact (Boko et al., 2007). This double threat on species is acute in the Mediterranean ecosystems region (Klausmeyer et al., 2009; Henne et al., 2013) which are is a hotspot of biodiversity (Myers et al., 2000) and where many relict and endemic species are endangered with extinction (Malcolm et al. 2006). In 2013, one of the most emblematic forest tree species in the Mediterranean, Atlas cedar (Cedrus atlantica (Endl.) Manetti ex Carrière), was added to the red list of the International Union for the Conservation of Nature ("The IUCN Red List of Threatened Species,"2019) as a threatened species to extinction in regard to the decreasing trend of its populations in Morocco and Algeria.

Morocco represents an ideal Mediterranean area for investigating the past impacts of environmental changes and anthropogenic activities on fragile ecosystems and endemic endangered species. As most of the Mediterranean countries, Morocco underwent an increasing aridity over the past five thousand years (Jalut et al., 2009) with a more pronounced trend over the last decades (Benassi, 2008, Bell et al., 2019). This natural climate aridification is observed worldwide (Maslin et al., 2001) and it has a direct marked impact on the Mediterranean forest ecosystems (Carrión et al., 2010; Colombaroliet al., 2009) through a decrease of the water availability and an increase of the fire frequency (Vannière et al., 2011).

Morocco represents an ideal area for investigating the past impacts of environmental changes and anthropogenic activities on ecosystems, particularly on mountain tree species. As most of the Mediterranean countries, Morocco underwent an increasing aridity over the past five thousand years (Jalut et al., 2009) with a more pronounced trend over the last decades (Benassi, 2008, Bell et al., 2019). In the Rif mountains the range of the endemic Atlas cedar decreased by about $75 \%$ within the past five decades (Cheddadi et al., 2017) due to the increasing drought. This natural climate aridification is observed worldwide (Maslin et al., 2001) but it is more acute and it has a direct marked impact on the Mediterranean forest ecosystems (Carrión et al., 2010; Colombaroli et al., 2009) through a decrease of the water availability and an increase of the fire frequency (Vannière et al., 2011). Morocco has a wide variety of landscapes and (micro)climates which have played a major role in maintaining a high ecosystem biodiversity. Today, about a quarter of the plant species in Morocco are 
endemic (e-Monograph of Moroccan Flora, 2016) and many, among which the Atlas cedar tree, are endangered to extinction ("The IUCN Red List of Threatened Species,"2019).

The ongoing climate warming and aridification in Morocco has a noticeable impact on the mountain ecosystems and particularly on the Atlas cedar forests (Linares et al., 2011a,b). Field observations (Rhanem, 2011) and vegetation model simulations (Cheddadi et al., 2017) show that the lower altitudinal limit migrated upwards by more than 100m within the past five decades. In the Rif mountains, populations of Atlas cedar became highly fragmented and the remaining populations are confined within microrefugia (sensu Rull, 2009) where local environmental conditions in the Moroccan mountains are still suitable and the human impact is reduced (Cheddadi et al., 2017). Microrefugia located in mountainous areas may offer suitable local conditions, including microclimate, for their long-term survival until a more favourable climate will allow their re-expansion.

In the present study, we investigate an area in the North-East of the Middle Atlas Mountains where a healthy population of Atlas cedar is isolated around a high altitudinal lake. We used a geographical information system (GIS) to analyze the topography of the catchment area and collected basic information about the modern local human occupancy in order to evaluate the potential long term persistence of the isolated population of Atlas cedar in situ under the ongoing climate change. In addition we collected a coring in the lake to investigate the relationship between the local populations of Atlas cedar and the recent local environmental changes.

\section{STUDY AREA}

Guelta Tameda is a temporary lake located in the North-East of the Middle Atlas mountains (figure 1). The water body is a floodplain area of $2 \mathrm{~km}$ long and $250 \mathrm{~m}$ wide which often dries in summer. A narrowing in the middle of the lake splits it into two parts. The upstream part in the south dries out at the beginning of spring. In the northeastern part the waters persist much longer than in the southern part depending on the annual amount of precipitation and the water extraction for local (small) agriculture. The area undergoes large annual and seasonal precipitation fluctuations. The water body may reach 46 ha at its maximum extension with a perimeter of $5 \mathrm{~km}$ and may have decreased decrease down to ca. 33 ha during severe droughts such as those that have occurred in North Africa between 1980 and 1990 (Tucker et al., 1991; Esper et al., 2007). Due to these annual lake level changes, the coring site of TAM01 
(figure 1) may be out of the water during the summer season which affects the chemical content of the sediment and leads to an enhanced degradation of the organic matter (pollen grains).

Guelta Tameda is a natural dam lake which probably formed as a result of a collapse or landslide of a limestone rock terrain that closed the incised valley to the north towards Tahfourt N'Ait Smaal. The slopes of the lake are steep varying between 50 and $70 \%$. The catchment area of about $64 \mathrm{~km}^{2}$, is surrounded by steep mountains whose altitudes vary between $1470 \mathrm{~m}$ and more than $2400 \mathrm{~m}$. The surrounding mountains are dolomitic limestones of the lower and middle Lias and soft formations of triassic mudstones (Colo, 1961) that are more than $70 \%$ covered by a dense mixed forest of Atlas cedar (Cedrus atlantica), evergreen oak (Quercus coccifera L.), deciduous oak (Q. canariensis Willd.) and pine (Pinus halepensis Mill.).

\section{MATERIAL AND METHODS}

\subsection{Terrain analysis}

The terrain ruggedness (or rugosity) index (TRI) is a measurement of the elevation difference between one grid cell and its eight adjacent cells over a digital area (Riley et al., 1999). The latter authors provided the following classification of the terrain rugosity:

Level $=0-80$

Nearly level $=81-116$

Slightly rugged $=117-161$

Intermediately rugged $=162-239$

Moderately rugged $=240-497$

Highly rugged $=498-958$

Extremely rugged $=959-4367$

The eight elevation difference values are squared (to obtain a positive value) then averaged. TRI corresponds to the square root of the averaged squares which provide an average elevation difference between each point of the cell gridded terrain (whatever the size of the grid cells is) and the adjacent cells (Riley et al., 1999). We used QGIS GIS (QGIS Development Team, 2019) to measure the TRI from a DEM (“EarthExplorer - Home," 1996) that covers the catchment area of Guelta Tameda and compared it to another area in the Rif mountains where fossil pollen records are 
available (figure 2).

\subsection{The sediment core in Lake Tameda}

In April 2017, we collected a 6 meter-long core $\left(33^{\circ} 48^{\prime} 51^{\prime \prime N}, 4^{\circ} 5^{\prime} 1^{\prime \prime} \mathrm{W}, 1470 \mathrm{~m}\right.$ asl) in Guelta Tameda (TAM01, figure 1) using a Russian corer of $50 \mathrm{~cm}$ length and $8 \mathrm{~cm}$ section. The total length of the coring consists of 12 sections of $50 \mathrm{~cm}$ each. We analyzed the clay minerals content using X-ray diffraction (XRD), the sediment grain size using a laser particle size analyzer, the chemical elements using an X-ray Fluorescence (XRF) and the fossil pollen grain content.

Eleven radiocarbon dates were obtained from organic bulk sediments (Table 1). We used CLAM (Blaauw, 2010) to perform a polynomial regression, weighted by the calibrated probabilities, for building an age/depth model for TAM01 (figure 3). The calibration curve used is IntCal13.14C. The calendar age point estimates for each depth is based on the weighted average of all age-depth curves. The low accuracy of the dated bulk sediment is related to the lack of organic macro-remains in TAM01, which would have certainly provided more accurate ${ }^{14} \mathrm{C}$ dates. The limestone catchment with probable variable hardwater effects (Lamb and van der Kaars, 1995) is a potential source of dating inaccuracy and may explain the reversed ages. These dating constraints might affect the confidence in the age model. The overall best linear model polynomial regression fits seven dates and excludes four dates which are outside the best fit. The age/depth model suggests that core TAM01 covers the last 2000 years. The age model provides an average sedimentation rate of ca. $3 \mathrm{~cm}$ per decade. The potential dating bias related to the hardwater effect of about 100 years for the last 2000 years (Lamb and van der Kaars, 1995) should not affect the conclusions of the present study as we do not focus on any specific centennial event but rather on the occurrence of the Atlas cedar in the Middle Atlas over the past few millennia and its relationship with the local environment.

Fossil pollen grains were extracted following a standard procedure using cold $\mathrm{HCl}(10 \%)$ then hot $\mathrm{KOH}(10 \%)$ to remove carbonates and soluble humic acids, respectively. Heavy liquid $\left(\mathrm{ZnCl}_{2}\right.$ with a 1.8 density) was used to separate by density difference the organic matter, including pollen grains, from sediment particles. Acetolysis (acetic Anhydric + sulfuric acid) at $80^{\circ} \mathrm{C}$ was finally used during 2 min to remove remaining organic matter. The remaining residue was diluted with a known volume of glycerin. The diluted residue of each fossil sediment sample was mounted in a microscope slide and the pollen grains were identified and counted using an 
optical microscope (Leica DM750). Below 190cm, we analyzed 41 samples which contained less than 100 pollen grains. These samples were discarded from the final pollen diagram and the sediment core between $600 \mathrm{~cm}$ and 190 , which corresponds to the time span between 2000 and 500 cal. BP, is considered as sterile. Pollen percentages of the remaining samples, from the upper part of TAM01, were computed using the total pollen sum (figure 4) which includes trees, shrubs and herbs but excludes local aquatic plants (Equisetum, Monolete and Trilete spores, and Polypodiaceae). The final sampling time resolution is ca. 30 years. We performed a constrained hierarchical clustering using R package "rioja" v0.9-21 (Juggins, 2017) with R v3.6.3 (R Core Team, 2020) to set up pollen zones (figure 4). The analysis was performed on the total number of taxa identified (81) in all fossil samples.

X-ray fluorescence (XRF) analyses were carried out using a Niton XL3t GOLDD. The $211 \mathrm{XRF}$ measurements were performed at $2 \mathrm{~cm}$ intervals between 180 and $600 \mathrm{~cm}$ with a counting time of 120 s using an acceleration intensity of $50 \mathrm{kV}$. XRF measurements are based on the spectral properties of the chemical elements, which when exposed to an X-ray source, emit X-ray fluorescence radiation. The latter is then detected by an XRF detector placed at $90^{\circ}$ with respect to the sediment surface. The processing of the recorded signal is then carried out by a software that analyses the variations in abundance (peaks) of the chemical elements through time. XRF analyses allowed us to estimate the content of 22 chemical elements among which we selected $\mathrm{Cu}, \mathrm{Pb}, \mathrm{Fe}, \mathrm{K}, \mathrm{Ca}$ and $\mathrm{Sr}$ (figure 5) as their content may be affected by human activities.

Nevertheless, many parameters can disrupt the measurement in geochemical analysis by micro-florescence $\mathrm{X}$, for example, the water content, the percentage of organic matter, the presence of shells and the particle size variations (Löwemark et al., 2011). The composition of the sediment in elements measurable by the XRF detector, including carbon, oxygen, and nitrogen, can reduce the number of strokes of the heaviest elements, which may cause a dilution effect. In other words, an increase in organic matter would result in a decrease in values and vice versa (Rollinson 1993). Thus, to overcome these limitations that could complicate the comparison of the sections of the same core, it becomes important to normalize the elements. This normalization would help preventing the interpretation of the variations from mirroring those of organic matter or carbonate. The most suitable element for normalization is Aluminum $(\mathrm{Al})$ as it is abundant and not subject to variations in redox conditions (Löwemark et al., 2011). The ratio is calculated by dividing the pm values of the 
elements, one by another. Due to technical problems it was not possible to perform the XRF analyses on the first $180 \mathrm{~cm}$ of core TAM01, which correspond to the top three sections of $50 \mathrm{~cm}$ each and the first $30 \mathrm{~cm}$ of the fourth section.

\section{RESULTS}

\subsection{Terrain ruggedness}

We have chosen to compare two areas which have similar geographical surfaces (ca. $40-50 \mathrm{~km}^{2}$ ) and where Atlas cedar occurs today as fragmented populations. The terrain analysis of rugosity in the NE part of the Middle Atlas provides high values, particularly within the catchment area of Guelta Tameda (figure 2) around which the mountain chain has the highest rugosity (TRI> 498). In the north-western Rif mountains, we observe much more lighter TRI values than in the NE of the Middle Atlas. As is the case around Lake Tameda, in the Rif area Atlas cedar occurs today only in those areas where the TRI is the highest. Fossil data in the studied Rif area (Cheddadi et al., 2017, see figure 2) show that Atlas cedar occurred during the recent few millennia even in areas with lower TRI than those where it occurs today. However, it is no longer present in areas with low TRI in the Rif mountains. Thus, in order to comprehend the adaptation of Atlas cedar in mountainous areas, with different rugosities, to past and potentially to expected future environmental changes, we complemented our GIS terrain data with the analysis of a sediment core from Lake Tameda.

\subsection{Sediment core analyses}

The sediments of TAM01 are rich in terrigenous elements mainly aluminosilicates ( $\mathrm{Al}, \mathrm{Fe}, \mathrm{K}, \mathrm{Ti}, \mathrm{Rb}$ and $\mathrm{V}$ ) particularly $\mathrm{Si}, \mathrm{Fe}, \mathrm{K}$ and $\mathrm{Ca}$. Changes in $\mathrm{Fe}$ content can be indicative of oxidation-reduction conditions in the lake, detrital inputs and changes in sediment source (Davison, 1993). Calcium contains both allogenic and authigenic sources, i.e. by erosion and transport and by carbonate precipitation successively (Cohen and McConnaughey, 2003). Geochemical elements play different roles within the lake system depending on the erosion process and the elements association. For instance, $\mathrm{Si}$ is generally abundant in quartz and many aluminosilicate minerals, which is a proxy of aeolian input. However, Si may also be associated with biogenic material (Martinez-Ruiz et al., 2015; Peinerud, 2000). Thus, its concentration in TAM01 may reflect either erosional processes related to higher runoff due to increased precipitation or to higher lake productivity related to higher 
concentrations of other nutrients. The Sr/Ca ratio (figure 6) provides an indication of calcium carbonate mineralogy. Calcite-dominated areas are marked by relatively low $\mathrm{Sr} / \mathrm{Ca}$ values while aragonite-dominated areas are characterized by high Sr/Ca values. This ratio also varies with depth and may suggest significant changes in precipitation over the catchment area.

Pollen grains are well preserved only in the upper $190 \mathrm{~cm}$, which cover the last 530 years (figure 4). However, due to technical issues XRF analyses were obtained only between $180 \mathrm{~cm}$ and $600 \mathrm{~cm}$ (figure 5) which encompasses the time span between 400 and 1900 years cal BP. As a matter of fact, the most important time span for detecting human disturbances in the Atlas mountains using XRF data is between 4000 and 500 cal BP (Cheddadi et al., 2015; 2019) where human activities are detectable by major changes in the geochemical elements such as iron, lead and copper. After 500 cal BP these chemical elements are less pertinent. Thus, the lack of overlap between pollen and XRF data is not crippling in this study since each environmental proxy is used for a different purpose.

Using a constrained hierarchical clustering over the pollen-reliable time span we depict four zones which are characterized by an alternation of the Atlas cedar and the evergreen oak (figure 4). Atlas cedar dominated between 530 and 450 cal. BP then between 250 and 125 cal. BP (pollen zones I and III) with pollen percentages higher than $40 \%$. The evergreen oak (Quercus ilex-type) was absent during pollen zone I then it dominated with Olea and Pinus between 450 and 250 cal. BP and again after 125 cal. BP (pollen zones II and IV). The herbaceous plants show minor changes between $450 \mathrm{cal}$. BP and the present. The main pollen markers of human activities within the Anthropogenic Pollen Index (API), which are usually considered as ruderals or related to human cultivation, are Centaurea and Plantago. These two pollen taxa (genera) have minor occurrences in TAM01 and none of their known species related to human activities ( $P$. lanceolata, $P$. major/media and $C$. cyanus, $C$. nigra, $C$. scabiosa) are present today in the study area. The overall trend of the arboreal pollen taxa and the occurrence of anthropogenic pollen markers do not indicate any potential causal effect of a local anthropogenic activity on the forest ecosystem.

\section{DISCUSSION}

Atlas cedar underwent a strong decline over the past decades (Cheddadi et al., 2017). The ongoing decline led to the extinction of some populations just over the past few decades, a reduction of the modern range and consequently a more pronounced 
fragmentation, and an upslope shift of the lower limit by about $200 \mathrm{~m}$ in some areas in the Middle Atlas (Rhanem, 2011). In the Rif mountains, the total range decreased by about $75 \%$ over the past five decades (Cheddadi et al., 2017). The declining trend of the Atlas cedars in Morocco is such that it has been added to the IUCN red list as a threatened species to extinction.

Atlas cedar is sensitive to recurrent drought (Kherchouche et al., 2013; Linares et al., 2013) while evergreen oak is tolerant to drought, even more than many other Mediterranean oak species (David et al., 2007). The observed alternation of Atlas cedar and evergreen oaks in the pollen diagram (figure 4) may be related to wetter and long lasting periods of drought. Thus, the time spans between 450 and $250 \mathrm{cal}$. $\mathrm{BP}$ then over the last 120 years, where the evergreen oaks expanded, are probably drier than the those between 250 and $120 \mathrm{cal}$. BP and prior to 450 where the Atlas cedar took over the evergreen oaks. However, depending on the studied area in the Moroccan mountains, one climate variable may have a more pronounced effect on the forest ecosystem composition than another one. An increase in summer aridity (Bell et al., 2019) or winter temperature (Cheddadi et al., 1998) or a decrease in the annual amount of precipitation or its seasonality (Cheddadi et al., 2017) or a complex combination of several climate variables have occurred in Moroccan mountains and they have impacted their ecosystems. In addition to the complex climate constraints, the human demography increased all throughout the Mediterranean during the Holocene (Palmisano et al., 2019) and human populations spread over the lowlands then in the mountainous regions (Cheddadi et al., 2019; Zhao et al., 2019). In Morocco, the natural climatic trend and the superimposed human impacts on the landscape became more pronounced over the past two thousands years with an even more marked imprint over the recent decades (Cheddadi et al., 2015; 2017). The ongoing loss of forest cover requires a scientific-based and low social cost strategy which can be an easily applicable solution for preserving the mountain forests in Morocco.

Whatever the explanation for the migration lags between the ongoing and/or expected velocity of the climate change, mainly warming (Loarie et al., 2009), and the migration rate of tree species, it seems that many species will not be able to track the expected global warming over the 21st century (Corlett and Westcott, 2013) and depending on different climate scenarios, the percentage of the species loss in the Mediterranean mountains might be very high (Thuiller et al., 2005). There are many options for preserving threatened plant species that are being debated. However, whatever the 
best scientific option is, we will be facing the problem of the necessary resources for its application in the southern edge of the Mediterranean. Thus, in order to increase the chances of applicability we believe that the conservation strategy should take into account the low public resources for applying the scientific recommendations.

One of the options that we are exploring to preserve the Atlas cedar in Morocco is to identify refugial areas where it occurs today and where it may have the highest chance to persist locally over a sufficient time span. This will allow the species to reach a more suitable future climate for recolonizing a more secure range. Most long-lived tree species, such as the Atlas cedar, have a migration rate that will probably be slower than the velocity of the ongoing climate change.

\section{Rugged mountains offer microrefugia for plant species}

Scientists have shown that topography can play an important buffer role in the local modulation of global or regional climates (Ashcroft et al., 2012; Dobrowski, 2011; Keppel et al., 2012, 2015). The multitude of potential local microclimates related to the complex climatic features of rugged mountains may play a key role in species diversity and persistence (Rahbek et al., 2019). Valencia et al. (2016) showed that mountains with high rugosity may provide more microrefugial areas (sensu Rull, 2009) for plant species under regional less favorable climate than areas with smoother landscapes. These microrefugial areas may represent an option for species conservation (Hannah et al., 2014) which may represent a realistic and low necessary resources option in North Africa.

We analyzed the terrain ruggedness and the modern human occupancy (figure 2) in two different areas in the Rif and the NE of the Middle Atlas where Atlas cedar occurs as fragmented populations at altitudes higher than 1400m. As expected, the number of human inhabitants is higher in areas where both the elevation and terrain ruggedness are low (figure 2). In the western part of the Rif mountains where pollen records indicate a decline to a local extinction of the Atlas cedar (Cheddadi et al., 2017; Abel-Schaad et al., 2018) the terrain ruggedness is lower and the human density is higher than around Tameda (figure 2). The small locations with high TRI (near Derdara and near Tanaqoub, see figure 2) have lower elevations than the modern lower limit of the Atlas cedar range (about 1400m). The two spots in the western Rif mountains with high rugosity and higher altitudes than 1400m (Jbel Kelti and Talassemtane national park) shelter small populations of Atlas cedars and have 
already been identified as microrefugia (Cheddadi et al., 2017).

\section{Low human impact in rugged mountains}

The analysis of fossil biological and geochemical elements from the Tameda record provides information on the timing and type of past human and natural impacts on the local vegetation. Many major chemical elements, (lead (Pb), iron (Fe) or copper (Cu)) which are used as markers of the human exploitation of the natural resources before and during the Roman period show no changes between 1900 and 400 cal BP (figure 4) that may be directly related to human activities near the site of Tameda. Several fossil records from the Middle Atlas and the Rif mountains show marked changes of these chemical elements (Cheddadi et al., 2015; Nour El Bait et al., 2014; Tabel et al., 2016) over the last 3000 years. Sr/Ca ratio (figure 6) suggest a rather noticeable change in the local or regional precipitation regime which may have impacted the runoff and annual fluctuations of the lake level more than human disturbances in the catchment area.

Unlike in many Mediterranean records (Walsh et al., 2019), the human pollen markers (figure 4) do not show any major changes and are not over-represented which suggests a minor human impact on the local vegetation over the last five centuries. In addition, Atlas cedar pollen record shows high frequencies over that time span and it is present today around the lake. Geochemical and pollen data clearly indicate that the area of Guelta Tameda was less impacted by human activities during the past 1900 years than other forest areas in the Middle Atlas (Lamb et al., 1991) and the Rif mountains (Cheddadi et al., 2015).

The modern Atlas cedars population around Guelta Tameda seem to be naturally protected from the ongoing decline of the species that is observed in the Rif and Atlas mountains. The local persistence of the species is related to the very low human density in the area and the difficult access to the forest ecosystem which covers the steep slopes of the mountain, due to its high ruggedness. The fossil record shows that the human impact was very limited and that the cedar forest persisted locally without declining trend. Thus, Guelta Tameda is a potential microrefugium area for the Atlas cedar and potentially for other species related to this conifer ecosystem.

In order to extend our knowledge of putative microrefugial areas we need to investigate other natural wetlands located at high altitudes where human activities 
have, and are still less impacting the landscape. Some of the wetlands in the Atlas and Rif mountains have been investigated and provided valuable environmental records. However, in the context of the ongoing global warming and in many areas, we still lack temporal high resolution studies of the recent past vegetation changes and human related inferences that may help us assess the impact of the natural climate variability and the anthropogenic activities in the southern part of the Mediterranean.

\section{Conservation Strategies}

Mountain regions with microrefugial areas which may offer suitable local microclimates would represent a faster option for tree species to cope with rapid climate changes (Cheddadi et al., 2017). The criteria to define these modern and potentially future refugial areas may be quite simple:

(1) they should offer a wide range of geological substrates, different exposures to both cold and/or warm climate and high topographic ruggedness to allow species to adapt more easily even with a low dispersal or migrational rate,

(2) they should have potential natural corridors to spread in and out to retract and/or colonize different areas as climate becomes more favorable or deteriorates through time,

(3) they should be as remote as possible from dense human populations or at least with very limited human occurrence and/or access. This is expected to minimize the investment of the public resources or reduce the cost for the conservation policies.

Besides these simple criteria, we need to evaluate the potential of species persistence over a period of time that is much longer than a century and evaluate its relationship to past environmental changes and recent human activities.

The studied site of Tameda fits these basic criteria as it has a rugged topography with corridors (see figure 1) which may serve as potential pathways for the species migration. The site is also distant from strong human inferences with remote main roads and isolated small villages where human populations are very low. Tameda should be considered as a potential microrefugial area for the long term preservation of the Atlas cedar in Morocco. 


\section{Conclusions}

In Morocco the total endemic plant species represent almost a quarter (>21\%) of the total (ca. 4200) species diversity (e-Monograph of Moroccan Flora, 2016). It is striking that the conservation of this biodiversity hotspot, which is expected to undergo major climate warming and increased severe drought over the next century (Hoerling et al., 2012), is still overlooked. Besides climate, there are multiple challenges which include the ever increasing human inferences and the lack of resources needed to the long term conservation of threatened species. Besides these biodiversity issues, mountain ecosystems with the endemic Atlas cedar are considered as water towers in Morocco because, unlike the steppe and shrublands, they help regulate the water flow into water tables. This is an additional reason why the Atlas cedar populations in Morocco are protected in several national parks and are considered as part of the national heritage.

The ongoing range reduction of Atlas cedar in Morocco already had an impact on the overall forest ecosystems and their social services. Conservation initiatives in the Southern Mediterranean countries often face the issue of limited financial and/or human resources for their application. Our study shows that mountain areas such as Guelta Tameda with a variety of natural resources and low human occupancy may provide suitable habitats for the long-lived tree species to survive to harsher regional/global climate changes and may serve as an excellent microrefugium for preserving threatened plant species.

In order to be efficient, scientific solutions for species conservation must integrate a realistic cost of their application on the field. In the present study, we suggest that the identification of microrefugia, using modern and fossil data, is probably the most efficient and easily applicable strategy for species conservation.

\section{AUTHORS CONTRIBUTIONS}

RC and YEH collected the Guelta Tameda TAM01 coring. MNEB and LB performed the pollen analyses. YEH performed the XRF and XRD analyses. YEH, NM and $\mathrm{RC}$ have written the original text. All co-authors have contributed to discussing and improving the manuscript content. We thank the LMC14 staff (Laboratoire de Mesure du Carbone-14), ARTEMIS national facility, UMS 2572 CNRS-CEA-IRDIRSN-MCC, for the results obtained with the Accelerator Mass Spectroscopy method. 


\section{Acknowledgments}

This work is a contribution to the Belmont Forum funded project VULPES (Project ID: ANR-15-MASC-0003). We thank Mr. Abdelghani Boutlalak for his valuable help during the fieldwork. We thank Laurent Dezileau for providing the XRF facility at the Geosciences lab in Montpellier.

\section{REFERENCES}

Abel-Schaad, D., Iriarte, E., López-Sáez, J.A, Pérez-Díaz, S., Sabariego Ruiz, S., Cheddadi, R. \& Alba-Sánchez, F. 2018. Does moroccan atlas cedar forests head to certain extinction? palaeoecological contributions to conservation and land management. The Holocene, 28(6) 1023-1037.

Ashcroft, M.B., Gollan, J.R., Warton, D.I., Ramp, D., 2012. A novel approach to quantify and locate potential microrefugia using topoclimate, climate stability, and isolation from the matrix. Global Change Biology 18, 1866-1879. https://doi.org/10.1111/j.1365-2486.2012.02661.x

Bell, B.A., Fletcher, W.J., Cornelissen, H.L., Campbell, J.F.E., Ryan, P., Grant, H., Zielhofer, C., 2019. Stable carbon isotope analysis on fossil Cedrus pollen shows summer aridification in Morocco during the last 5000 years. J. Quaternary Sci. 34, 323-332. https://doi.org/10.1002/jqs.3103

Benassi, M., 2008. Drought and climate change in Morocco. Analysis of precipitation field and water supply. Options méditerranéennes, 80, pp.83-87.

Blaauw, M., 2010. Methods and code for 'classical' age-modelling of radiocarbon sequences. Quaternary Geochronology 5, 512-518. https://doi.org/10.1016/j.quageo.2010.01.002

Boko, M., Niang, I., Nyong, A., Vogel, A., Githeko, A., Medany, M., Osman-Elasha, B., Tabo, R. and Yanda, P.Z., 2018. Africa Climate Change 2007: Impacts, Adaptation and Vulnerability: Contribution of Working Group II to the Fourth Assessment Report of the Intergovernmental Panel on Climate Change.

Carrión, J.S., Fernández, S., González-Sampériz, P., Gil-Romera, G., Badal, E., Carrión-Marco, Y., López-Merino, L., López-Sáez, J.A., Fierro, E., Burjachs, F., 2010. Expected trends and surprises in the Lateglacial and Holocene vegetation history of the Iberian Peninsula and Balearic Islands. Review of Palaeobotany and Palynology, Iberian Floras through Time: Land of Diversity and Survival 162, 458-475. https://doi.org/10.1016/j.revpalbo.2009.12.007 
Cheddadi, R., Lamb, H.F., Guiot, J., van der Kaars, S., 1998. Holocene climatic change in Morocco: a quantitative reconstruction from pollen data. Climate Dynamics 14, 883-890. https://doi.org/10.1007/s003820050262

Cheddadi, R., Nourelbait, M., Bouaissa, O., Tabel, J., Rhoujjati, A., López-Sáez, J.A., Alba-Sánchez, F., Khater, C., Ballouche, A., Dezileau, L., Lamb, H., 2015. A History of Human Impact on Moroccan Mountain Landscapes. Afr Archaeol Rev 32, 233-248. https://doi.org/10.1007/s10437-015-9186-7

Cheddadi, R., Henrot, A.-J., François, L., Boyer, F., Bush, M., Carré, M., Coissac, E., De Oliveira, P.E., Ficetola, F., Hambuckers, A., Huang, K., Lézine, A.-M., Nourelbait, M., Rhoujjati, A., Taberlet, P., Sarmiento, F., Abel-Schaad, D., AlbaSánchez, F., Zheng, Z., 2017. Microrefugia, Climate Change, and Conservation of Cedrus atlantica in the Rif Mountains, Morocco. Front. Ecol. Evol. 5. https://doi.org/10.3389/fevo.2017.00114

Cheddadi, R., Palmisano, A., López-Sáez, J.A., Nourelbait, M., Zielhofer, C., Tabel, J., Rhoujjati, A., Khater, C., Woodbridge, J., Lucarini, G., Broodbank, C., Fletcher, W.J., Roberts, C.N., 2019. Human demography changes in Morocco and environmental imprint during the Holocene. The Holocene 29, 816-829. https://doi.org/10.1177/0959683619826657

Cohen, A.L., McConnaughey, T.A., 2003. Geochemical Perspectives on Coral Mineralization. Reviews in Mineralogy and Geochemistry 54, 151-187. https://doi.org/10.2113/0540151

Colo, G., 1961. Contribution à l'étude du Jurassique du Moyen Atlas septentrional. Ed. de la Division de la géologie, Rabat, Maroc.

Colombaroli, D., Tinner, W., Leeuwen, J.V., Noti, R., Vescovi, E., Vannière, B., Magny, M., Schmidt, R., Bugmann, H., 2009. Response of broadleaved evergreen Mediterranean forest vegetation to fire disturbance during the Holocene: insights from the peri-Adriatic region. Journal of Biogeography 36, 314-326. https://doi.org/10.1111/j.1365-2699.2008.01987.x

Corlett, R. T., \& Westcott, D. A. 2013. Will plant movements keep up with climate change? Trends in Ecology and Evolution, 28(8), 482-488. https://doi.org/10.1016/j.tree.2013.04.003

David, T. S., Henriques, M. O., Kurz-Besson, C., Nunes, J., Valente, F., Vaz, M., Pereira, J. S., Siegwolf, R., Chaves, M. M., Gazarini, L. C., \& David, J. S. (2007). Water-use strategies in two co-occurring Mediterranean evergreen oaks: 
Surviving the summer drought. Tree Physiology, 27(6), 793-803. https://doi.org/10.1093/treephys/27.6.793

Davison, W., 1993. Iron and manganese in lakes. Earth-Science Reviews 34, 119163. https://doi.org/10.1016/0012-8252(93)90029-7

Dobrowski, S.Z., 2011. A climatic basis for microrefugia: the influence of terrain on climate: A CLIMATIC BASIS FOR MICROREFUGIA. Global Change Biology 17, 1022-1035. https://doi.org/10.1111/j.1365-2486.2010.02263.x

e-Monograph of Moroccan Flora. Version 1, January 2016. [Database continuously updated]. http://herbaria.plants.ox.ac.uk/bol/Morocco (accessed 1/03/2020)

EarthExplorer - Home [WWW Document], 1996. URL https://earthexplorer.usgs.gov/ (accessed 1.6.20).

Esper, J., Frank, D., Büntgen, U., Verstege, A., Luterbacher, J., and Xoplaki, E. (2007). Long-term drought severity variations in Morocco. Geophys. Res. Lett. 34, 1-5. doi: 10.1029/2007GL030844

Google Earth V 7.3.2.5776. (2018). Guelta Tamda, Morocco. 3349’51.65”N, 403'54.35”W, elevation 1702M. 3D map, viewed January 19, 2020. <http://www.google.com/earth/index.html>.

Hannah, L., Flint, L., Syphard, A.D., Moritz, M.A., Buckley, L.B., McCullough, I.M., 2014. Fine-grain modeling of species' response to climate change: holdouts, stepping-stones, and microrefugia. Trends in Ecology \& Evolution 29, 390-397. https://doi.org/10.1016/j.tree.2014.04.006

Henne, P. D., Elkin, C., Colombaroli, D., Samartin, S., Bugmann, H., Heiri, O., \& Tinner, W. (2013). Impacts of changing climate and land use on vegetation dynamics in a Mediterranean ecosystem: Insights from paleoecology and dynamic modeling. Landscape Ecology, 28(5), 819-833. https://doi.org/10.1007/s10980-012-9782-8

Hoerling, M., Eischeid, J., Perlwitz, J., Quan, X., Zhang, T., Pegion, P., 2012. On the Increased Frequency of Mediterranean Drought. J. Climate 25, 2146-2161. https://doi.org/10.1175/JCLI-D-11-00296.1

Jalut, G., Dedoubat, J. J., Fontugne, M., \& Otto, T. (2009). Holocene circumMediterranean vegetation changes: Climate forcing and human impact. Quaternary International, 200(1-2), 4-18. doi.org/10.1016/j.quaint.2008.03.012 Juggins, S. (2017). rioja: Analysis of Quaternary Science Data, R package version (0.9-21). (http://cran.r-project.org/package=rioja). 
Keppel, G., Mokany, K., Wardell-Johnson, G.W., Phillips, B.L., Welbergen, J.A., Reside, A.E., 2015. The capacity of refugia for conservation planning under climate change. Frontiers in Ecology and the Environment 13, 106-112.

Keppel, G., Van Niel, K.P., Wardell-Johnson, G.W., Yates, C.J., Byrne, M., Mucina, L., Schut, A.G.T., Hopper, S.D., Franklin, S.E., 2012. Refugia: identifying and understanding safe havens for biodiversity under climate change: Identifying and understanding refugia. Global Ecology and Biogeography 21, 393-404. https://doi.org/10.1111/j.1466-8238.2011.00686.x

Kherchouche, D., Kalla, M., Gutierrez, E., Briki, A., \& Hamchi, A. (2013). La sécheresse et le dépérissement du cèdre de l'Atlas (Cedrus atlantica Manetti) dans le massif du Belezma (Algérie). Sécheresse, 24, 129-137. https://doi.org/10.1684/sec.2010.0256

Klausmeyer, K. R., \& Shaw, M. R. (2009). Climate change, habitat loss, protected areas and the climate adaptation potential of species in mediterranean $\begin{array}{llll}\text { ecosystems } \quad \text { worldwide. } & \text { PLoS }\end{array}$ https://doi.org/10.1371/journal.pone.0006392

Lamb, H.F., Damblon, F., Maxted, R.W., 1991. Human Impact on the Vegetation of the Middle Atlas, Morocco, During the Last 5000 Years. Journal of Biogeography 18, 519-532. https://doi.org/10.2307/2845688

Lamb, H. F., \& van der Kaars, S. (1995). Vegetational response to Holocene climatic change: pollen and palaeolimnological data from the Middle Atlas, Morocco. The Holocene, 5(4), 400-408.

Linares, J. C., Seco, J. I., \& Carreira, J. A. (2011a). Tree growth decline on relict western-Mediterranean mountain forests: causes and impacts. In Joshua A. Jenkins (Ed.), Forest decline: causes and impacts (pp. 1-20). Nova Science.

Linares, J. C., Taïqui, L., \& Camarero, J. J. (2011b). Increasing Drought Sensitivity and Decline of Atlas Cedar (Cedrus atlantica) in the Moroccan Middle Atlas Forests. Forests, 2(3), 777-796. https://doi.org/10.3390/f2030777

Linares, J. C., Taïqui, L., Sangüesa-Barreda, G., Seco, J. I., \& Camarero, J. J. (2013). Age-related drought sensitivity of Atlas cedar (Cedrus atlantica) in the Moroccan Middle Atlas forests. Dendrochronologia, 31(2), 88-96. https://doi.org/10.1016/j.dendro.2012.08.003 
Loarie, S.R., Duffy, P.B., Hamilton, H., Asner, G.P., Field, C.B., Ackerly, D.D., 2009. The velocity of climate change. Nature 462, 1052-1055. https://doi.org/10.1038/nature08649

Löwemark, L., Chen, H.-F., Yang, T.-N., Kylander, M., Yu, E.-F., Hsu, Y.-W., Lee, T.Q., Song, S.-R., Jarvis, S., 2011. Normalizing XRF-scanner data: A cautionary note on the interpretation of high-resolution records from organic-rich lakes. Journal of Asian Earth Sciences 40, 1250-1256. https://doi.org/10.1016/j.jseaes.2010.06.002

Malcolm, J. R., Liu, C., Neilson, R. P., Hansen, L., \& Hannah, L. (2006). Global warming and extinctions of endemic species from biodiversity hotspots. Conservation Biology, 20(2), 538-548. https://doi.org/10.1111/j.15231739.2006.00364.x

Martinez-Ruiz, F., Kastner, M., Gallego-Torres, D., Rodrigo-Gámiz, M., Nieto-Moreno, V., Ortega-Huertas, M., 2015. Paleoclimate and paleoceanography over the past $20,000 \mathrm{yr}$ in the Mediterranean Sea Basins as indicated by sediment elemental proxies. Quaternary Science Reviews 107, 25-46. https://doi.org/10.1016/j.quascirev.2014.09.018

Maslin, M., Stickley, C., Ettwein, V., 2001. Holocene Climate Variability, in: Encyclopedia of Ocean Sciences. Elsevier, pp. 1210-1217. https://doi.org/10.1006/rwos.2001.0246

Myers, N., Mittermeier, R.A., Mittermeier, C.G., Fonseca, G.A.B. da, Kent, J., 2000. Biodiversity hotspots for conservation priorities. Nature 403, 853-858.

Nour El Bait, M., Rhoujjati, A., Eynaud, F., Benkaddour, A., Dezileau, L., Wainer, K., Goslar, T., Khater, C., Tabel, J., Cheddadi, R., 2014. An 18 000-year pollen and sedimentary record from the cedar forests of the Middle Atlas, Morocco. Journal of Quaternary Science 29, 423-432. https://doi.org/10.1002/jqs.2708

Nourelbait, M., Rhouijati, A., Benkaddour, A., Carré, M., Eynaud, F., Martinez, P., Cheddadi, R., 2015. Climate changes since the mid-Holocene in the Middle Atlas, Morocco. Clim. Past Discuss. 11, 4097-4121. https://doi.org/10.5194/cpd11-4097-2015

Palmisano, A., Woodbridge, J., Roberts, C.N., Bevan, A., Fyfe, R., Shennan, S., Cheddadi, R., Greenberg, R., Kaniewski, D., Langgut, D., Leroy, S.A., Litt, T., Miebach, A., 2019. Holocene landscape dynamics and long-term population 
trends in the Levant. The Holocene 29, 708-727. https://doi.org/10.1177/0959683619826642

Peinerud, E.K., 2000. Interpretation of Si concentrations in lake sediments: three case studies. Environmental Geology 40, 64-72. https://doi.org/10.1007/PL00013330 QGIS Development Team (2019). QGIS Geographic Information System. Open Source Geospatial Foundation Project. http://qgis.osgeo.org

R Core Team, 2020. R: A Language and Environment for Statistical Computing.

Rahbek, C., Borregaard, M. K., Colwell, R. K., Dalsgaard, B., Holt, B. G., MoruetaHolme, N., Nogues-Bravo, D., Whittaker, R. J., \& Fjeldså, J. (2019). Humboldt's enigma: What causes global patterns of mountain biodiversity? Science (New York, N.Y.), 365(6458), 1108-1113. https://doi.org/10.1126/science.aax0149

Rhanem, M., 2011. Aridification du climat régional et remontée de la limite inférieure du cèdre de l'Atlas (Cedrus atlantica Manetti) aux confins de la plaine de Midelt (Maroc). Physio-Géo. Géographie physique et environnement 143-165. https://doi.org/10.4000/physio-geo.1983

Riley, S., DeGloria, S.D., Elliot, R., 1999. A terrain ruggedness index that quantifies topographic heterogeneity. Intermountain Journal of sciences, 5(1-4), 23-27.

Rollinson, H.R. 1949-, 1993. Using geochemical data: evaluation, presentation, interpretation /. Longman Scientific \& Technical ; 353 p.

Rull, V., 2009. Microrefugia. Journal of Biogeography 36, 481-484. https://doi.org/10.1111/j.1365-2699.2008.02023.x

Tabel, J., Khater, C., Rhoujjati, A., Dezileau, L., Bouimetarhan, I., Carre, M., Vidal, L., Benkaddour, A., Nourelbait, M., Cheddadi, R., 2016. Environmental changes over the past 25000 years in the southern Middle Atlas, Morocco: PAST ENVIRONMENTAL CHANGES IN MOROCCO. J. Quaternary Sci. 31, 93-102. https://doi.org/10.1002/jqs.2841

The IUCN Red List of Threatened Species [WWW Document], 2019. IUCN Red List of Threatened Species. URL https://www.iucnredlist.org/en (accessed 2.6.20).

Thuiller, W., Lavorel, S., Araújo, M. B., Sykes, M. T., \& Prentice, I. C. (2005). Climate change threats to plant diversity in Europe. Proceedings of the National Academy of Sciences of the United States of America, 102(23), 8245-8250.

Tucker, C. J., Dregne, H. E., and Newcomb, W. W. (1991). Expansion and contraction of he Sahara desert from 1980 to 1990. Science 253, 299-301. doi: 10.1126/science.253.5017.299 
Valencia, B.G., Matthews-Bird, F., Urrego, D.H., Williams, J.J., Gosling, W.D., Bush, M., 2016. Andean microrefugia: testing the Holocene to predict the Anthropocene. New Phytol 212, 510-522. https://doi.org/10.1111/nph.14042

Vannière, B., Power, M.J., Roberts, N., Tinner, W., Carrión, J., Magny, M., Bartlein, P., Colombaroli, D., Daniau, A.L., Finsinger, W., Gil-Romera, G., Kaltenrieder, P., Pini, R., Sadori, L., Turner, R., Valsecchi, V., Vescovi, E., 2011. CircumMediterranean fire activity and climate changes during the mid-Holocene environmental transition (8500-2500 cal. BP). The Holocene 21, 53-73. https://doi.org/10.1177/0959683610384164

Walsh, K., Berger, J. F., Roberts, C. N., Vanniere, B., Ghilardi, M., Brown, A. G., Woodbridge, J., Lespez, L., Estrany, J., Glais, A., Palmisano, A., Finné, M., \& Verstraeten, G. (2019). Holocene demographic fluctuations, climate and erosion in the Mediterranean: A meta data-analysis. Holocene, 29(5), 864-885. https://doi.org/10.1177/0959683619826637

Wiens, J.J., 2016. Climate-Related Local Extinctions Are Already Widespread among Plant and Animal Species. PLOS Biology 14, e2001104. https://doi.org/10.1371/journal.pbio.2001104

Zhao, X, Dupont, LM, Cheddadi, R, Kölling, M, Reddad, H, Groeneveld, J, Ain-Lhout, FZ and Bouimetarhan, I (2019) Recent climatic and anthropogenic impacts on endemic species in southwestern Morocco. Quaternary Science Reviews, 221

\section{Figure and table legends}

Figure 1. Map of the studied area in the Middle Atlas mountains in Morocco (Google Earth, 2018), showing the location and the morphology of Guelta Tameda and the coring site of TAM01. The colored lines provide an approximate elevation around the studied site. The picture at the top left shows the location of the TAM01 core and the Guelta Tameda with a mixed evergreen oak/ Atlas cedar forest surrounding the site.

Figure 2. Terrain ruggedness index (TRI) of North-West part of the Rif mountains (top panel), TRI of the catchment area of Guelta Tameda in the North-East part of the Middle Atlas (lower panel), and the cedar occurrence in both sites. The pollen percentages of the two sites located in the Rif Mountains (Mhad and Bab El Karn, Cheddadi et al., 2017) are shown in the top panel. 
Figure 3. Age/depth model for TAM01 using CLAM software (Blaauw, 2010). The linear model fits seven accepted dates (blue). Four dates (red) do not fit the polynomial age/depth model.

Figure 4. Pollen diagram of core TAM01 showing relative abundances of the main trees and shrubs taxa, percentages of anthropogenic pollen markers (API = Anthropogenic Pollen Index; RPI = regional pastoral indicators; $\mathrm{ANH}=$ Anthropogenic nitrophilous herbs; OJCV = Olea-Juglans-Castanea-Vitis, see Cheddadi et al. (2019)), arboreal pollen taxa (AP), and constrained hierarchical clustering.

Figure 5. X-Ray Fluorescence measured copper ( $\mathrm{Cu}$ ), lead ( $\mathrm{Pb})$, iron (Fe), potassium $(\mathrm{K})$, calcium $(\mathrm{Ca})$ and strontium $(\mathrm{Sr})$ normalized by $\mathrm{Al}$. The dashed black line shows the overlap between the XRF and pollen data.

Figure 6. Moving average of z-scores of the $\mathrm{Sr} / \mathrm{Ca}$ ratio. z-score is a measure of the standard deviations that describes the distance of an element from the mean value. It is calculated according to the following formula: $z=(x-\mu) / \sigma$ where, $x=$ variable,$\mu=$ mean value,$\sigma=$ standard deviation).

Table 1. Eleven $14 \mathrm{C}$ dates obtained for core TAM01. The age/depth model developed in figure 3 is based on seven dates (blue) and excludes four dates (red). Calibrated ages ranges are at $95 \%$ confidence intervals. 


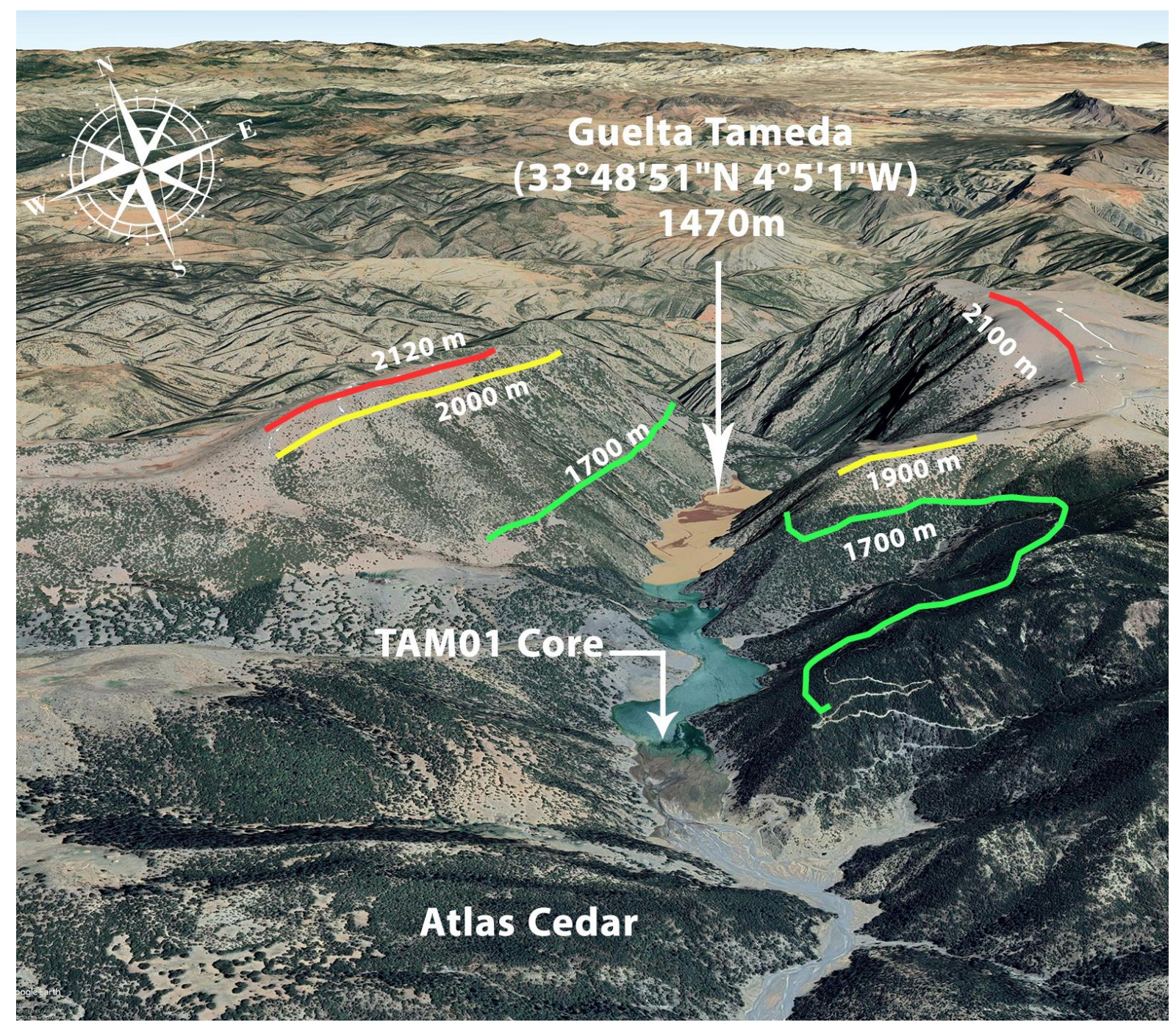

Figure 1 


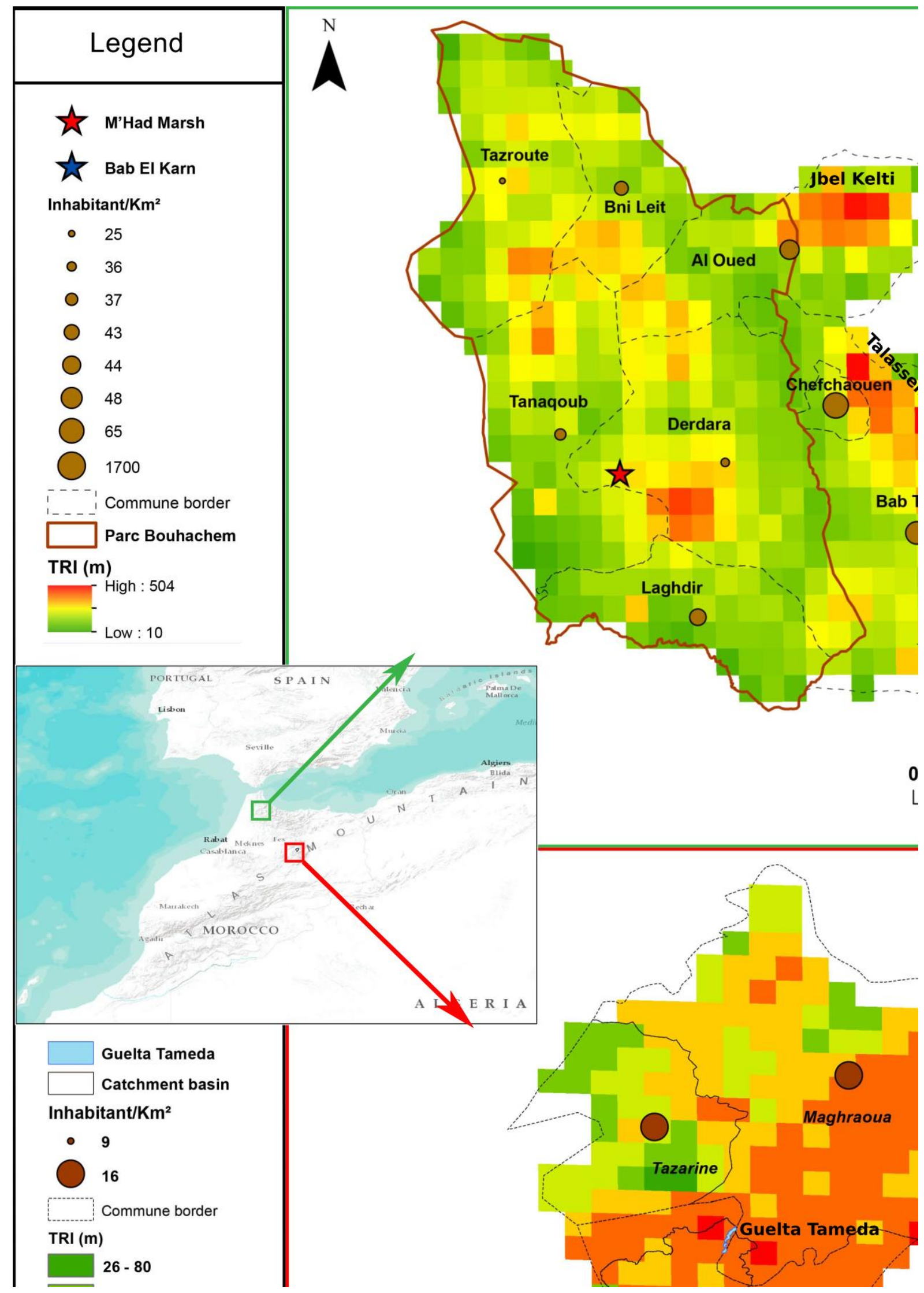

Figure 2 


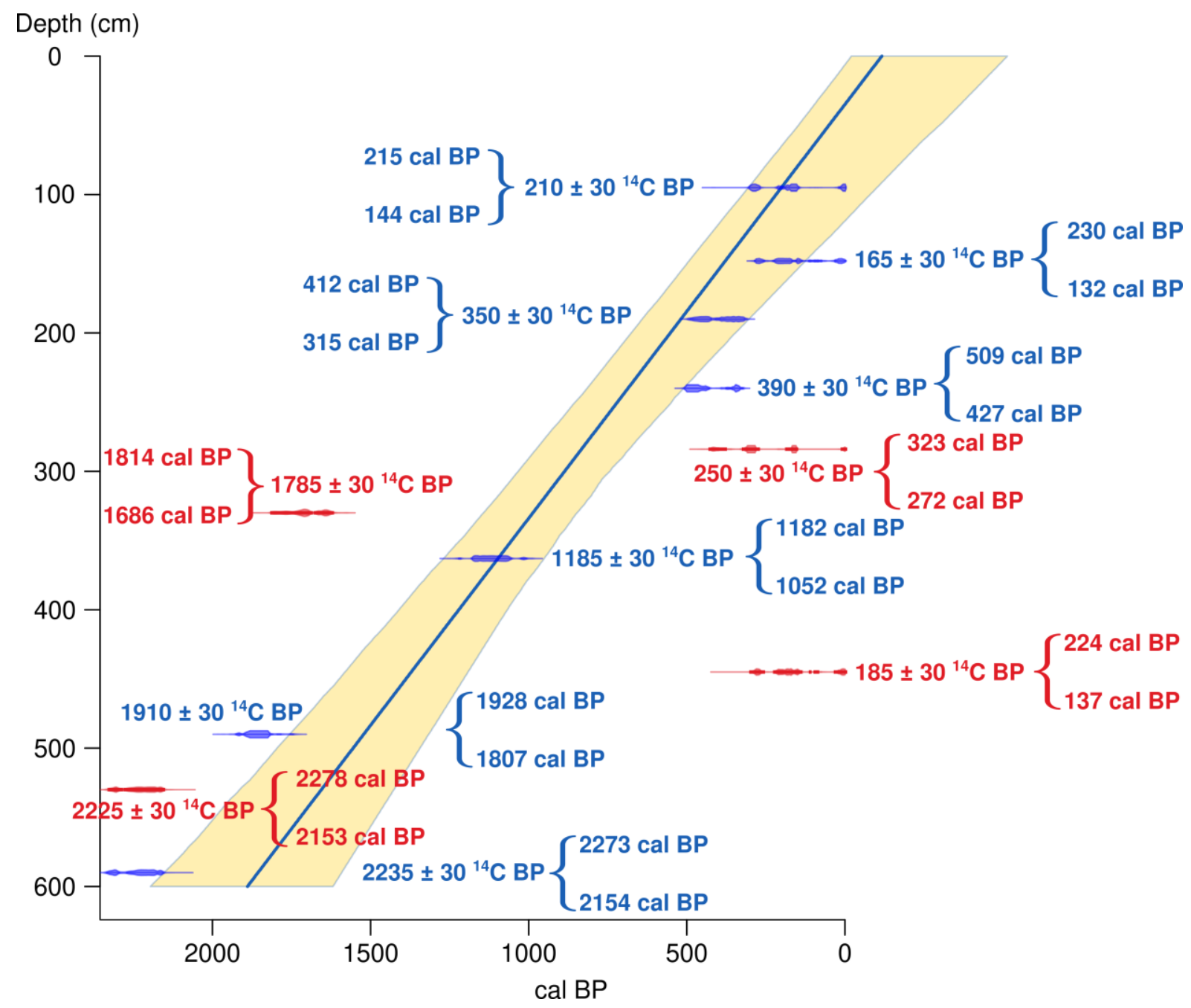

Figure 3 


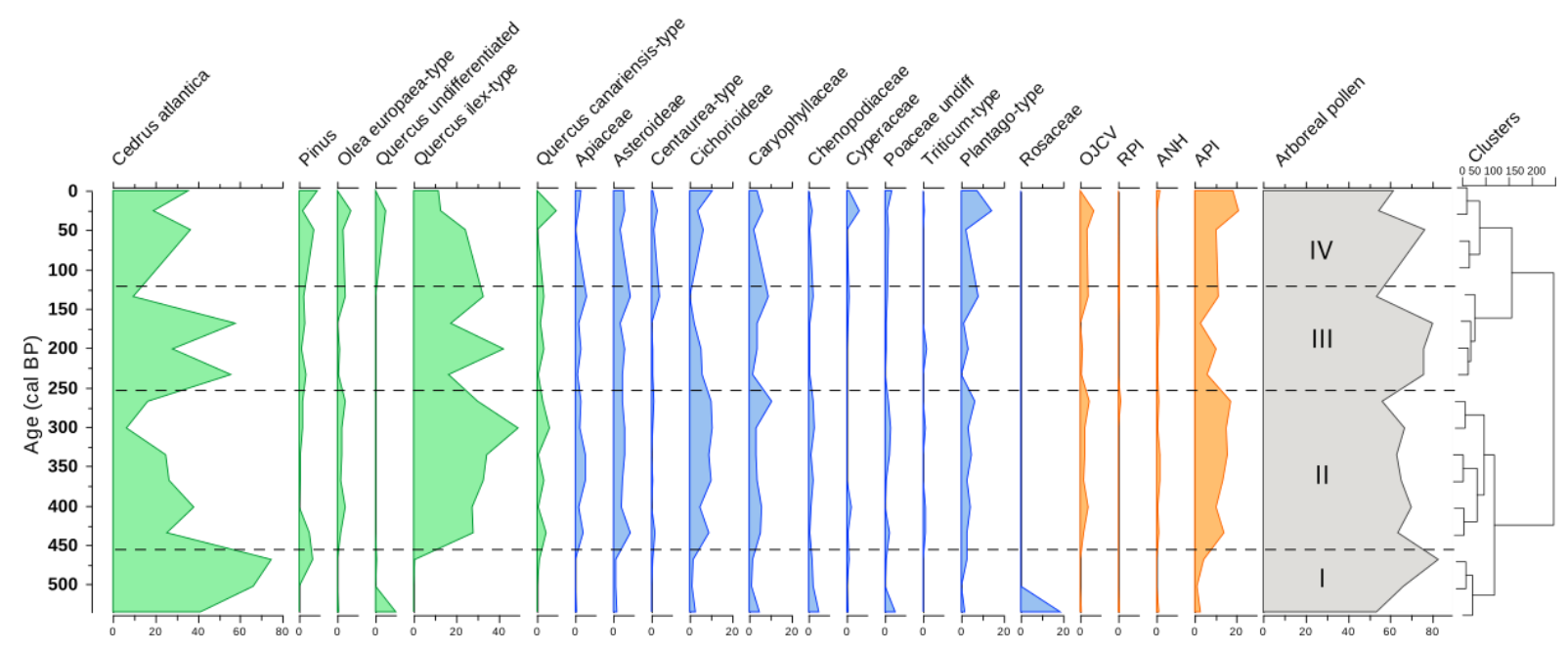

Figure 4 


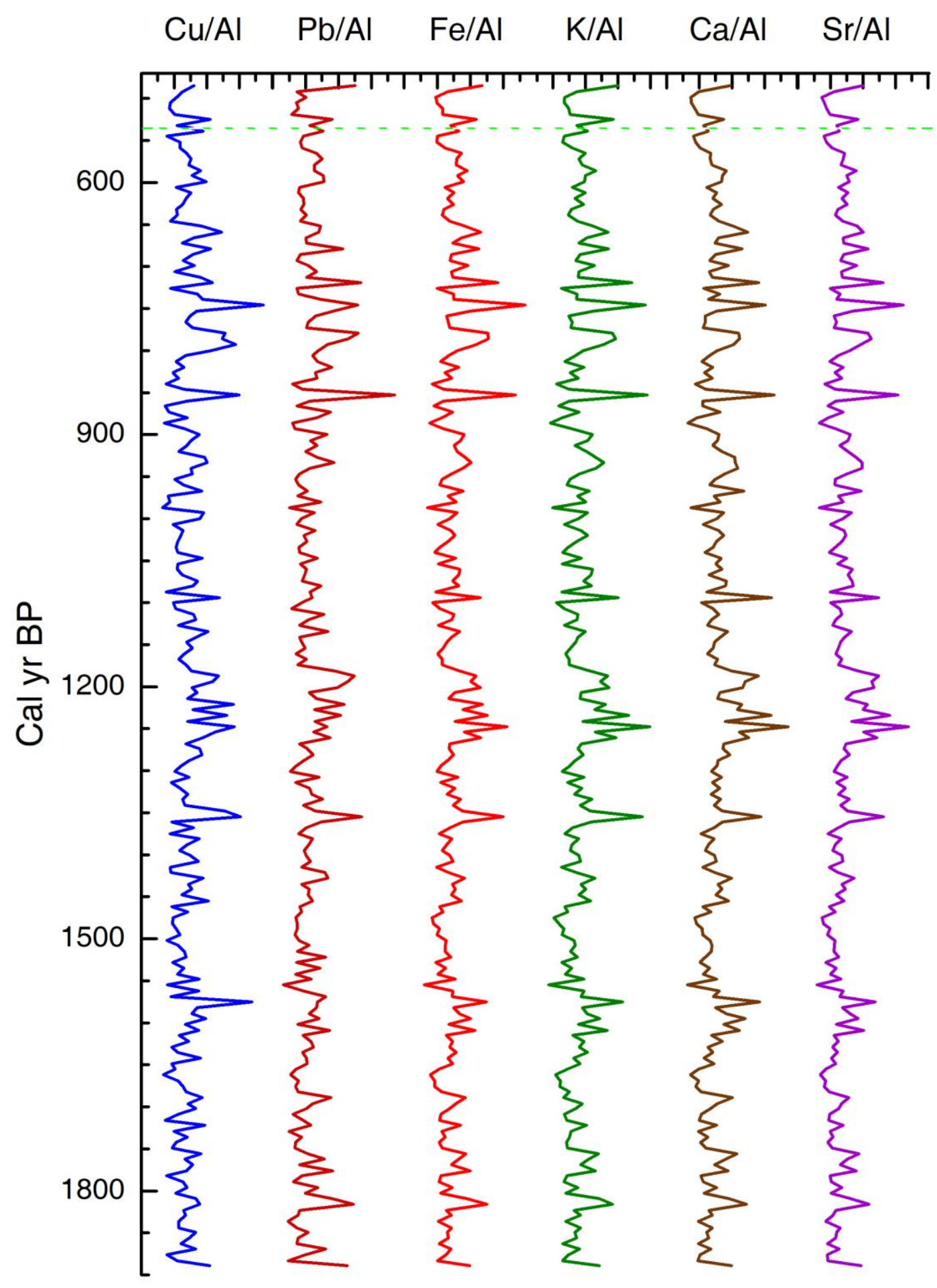

Figure 5 


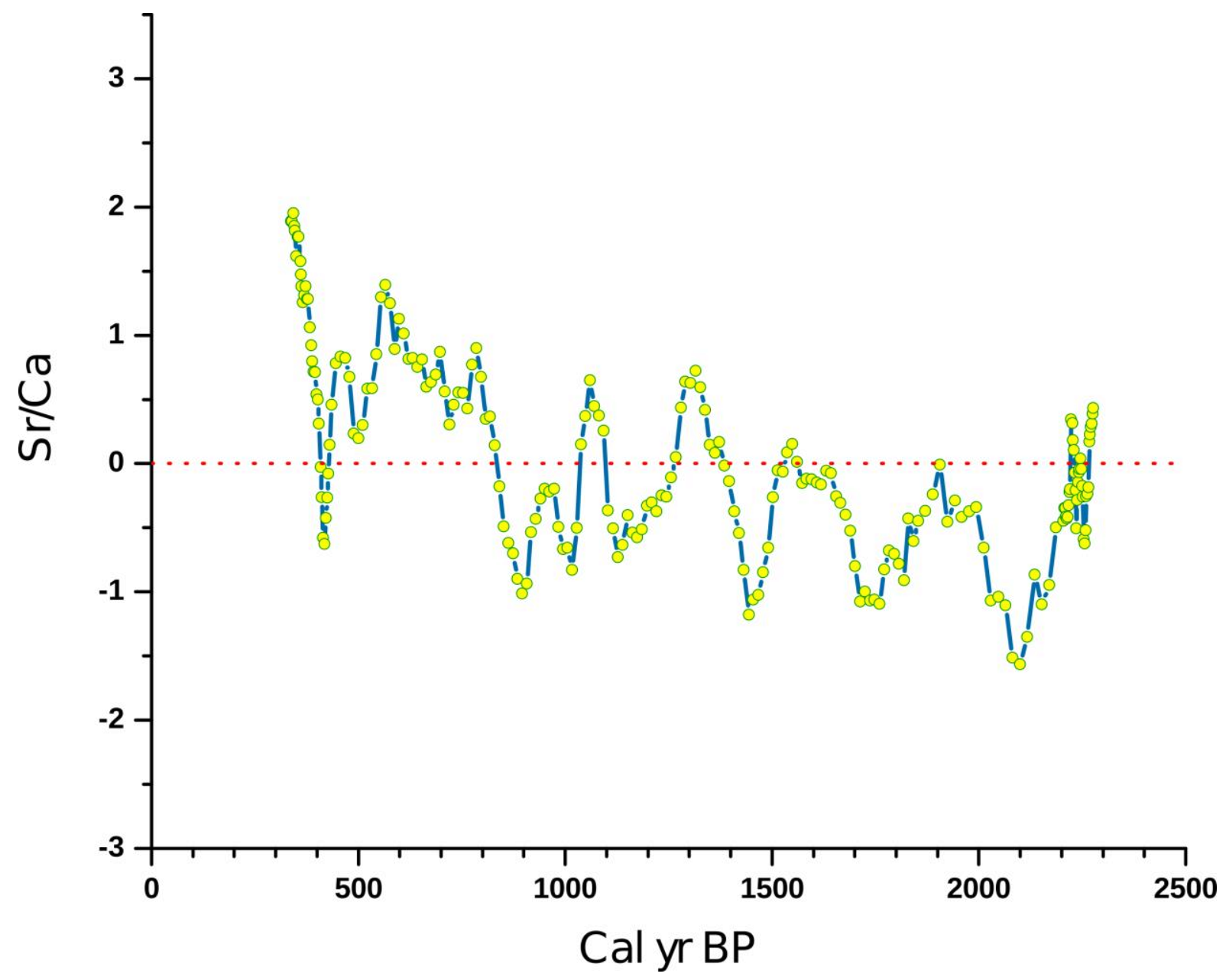

Figure 6 